\title{
Organ Donation: Experience in the Maintenance of a Brain-Dead Donor
}

1 Petra Urbič Jurak

2 Andrej Starc

1 Medical Centre Rogaška Slatina, Zdravstvo d.o.o.

2 Faculty of Health Sciences, Chair of Public Health, Slovenia, University of Ljubljana undecided about the donation of their own organs are against organ donation in general. It has been shown that there is a lack of education and communication on the maintenance of brain-dead donors.

Conclusions: Work with brain-dead donors is almost routine work in intensive care units. Some healthcare professionals perceive a brain-dead organ donor like any other patient, but within a defined protocol.

\begin{abstract}
Background: Brain death is an irreversible biological event, and is the permanent cessation of functions of the brain and brainstem. Transplantation has become an established method of treatment of many, near-terminal patients.
\end{abstract}

Methods: The sample consisted of three groups: doctors, registered nurses, and nursing assistants. The research was carried out in the Intensive Care Unit of the University Medical Centre Ljubljana, Department of Anaesthesiology and Surgical Intensive Therapy Department and at the Clinical Department of Vascular Neurology and Intensive Neurological Therapy. Data were collected using a questionnaire and semi-structured interviews.

Results: Women experience more stress when working with brain-dead donors than men do. We conclude that the work with a brain-dead organ donor represents a specific situation and has little in common with the factors that affect the overall satisfaction of healthcare professionals. Healthcare professionals who are
Keywords: brain death, transplantation activity, brain-dead organ donor, stress, experiences of health professionals.

Article received: 01.03.2018.

Article accepted: 20.03.2018.

DOI: $10.24141 / 1 / 4 / 1 / 2$

Author for correspondence:

Asst. Prof. Andrej Starc, PhD, BSc(RN), BSc(Ed.)

Faculty of Health Sciences, Chair of Public Health, Slovenia, University of Ljubljana

Zdravstvena pot 5, 1000 Ljubljana, Slovenia

Phone: +38613001111

Fax: +356130011 19

Email: andrej.starc@guest.arnes.si 


\section{Introduction}

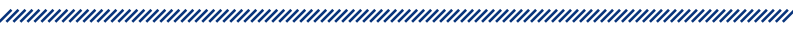

Organ donation is a complex process of the detection of possible dead donors, diagnosis of brain death, communication with relatives, and the maintenance of donors' circulatory system for quality organ removal. Authors have argued for the importance of highly educated healthcare professionals ${ }^{1}$. Death itself is an irreversible phenomenon, presented as the cessation of the functioning of vital organs, and the permanent absence of brain and brainstem function ${ }^{2}$, beginning with an apnoeic unresponsive coma. Breathing, circulation, normal body temperature, liquid, electrolytic and acid-base balance are maintained to prevent possible infections, and several clinical investigations occur ${ }^{3}$. Healthcare professionals are faced with the so-called paradox of the brain-dead person: a person who still breathes and still feels warm when touched. Not just relatives, but also healthcare professionals, are faced with doubts, emotional distress, stress, and sadness.

Healthcare professionals become too involved in the pain and sadness and begin to relive past events. They may also perceive a brain-dead person in the same way as other patients and see an opportunity to preserve the lives of other people ${ }^{4}$. Different moral, religious, philosophical, and cultural beliefs and aspects can influence everyday practice in relation to the relatives and the process of donation and transplantation ${ }^{5}$.

The understanding, perception, and acceptance of the concept of brain death are mostly based on internal ethical conflicts. Not only ordinary people, but also some healthcare professionals express their doubt, perception, and frustration in relation to "this is not the end"

\section{Methodology}

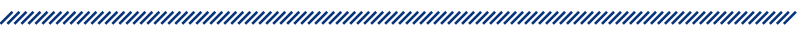

We used a quantitative and qualitative methodology. The sample consisted of three groups: doctors, registered nurses, and nursing assistants. All three groups of healthcare providers were recruited from the Intensive Care Unit (ICU) of the University Medical Centre Ljubljana, Department of Anaesthesiology and Surgical Intensive Therapy Department and the Clinical Department of Vascular Neurology and Intensive Neurological Therapy.
Ethical approval was obtained prior to the commencement of the study.For the quantitative analysis, a validated questionnaire was used. In the initial phase, a pilot study was conducted, which lasted from 8 to 22 September 2014. Along with the participants' demographics, the questionnaire included statements (5-scale Likert), which measured the individuals' working environment $(\alpha=.750)$ and the way of coping with stress $(\alpha=.690)$.

For the qualitative analysis ${ }^{9-10}$, semi-structured interviews were conducted with five sets of questions, summarized by a validated instrument ${ }^{11}$.

Following validation, the research lasted from 1 October until 20 December 2014. The eligibility criteria required that the participants possessed adequate levels of education and that they were employed at the clinical departments where the study was carried out.

The questionnaire consisted of 28 open-ended, one closed-ended and seven compound questions. Other data were demographic data, a set of statements regarding the individual's working environment, organ donation, feelings and work with dead donors, possible disburdening after the work and meetings with relatives. For some questions (numbers 5, 15, 23, 25) a validated instrument was used ${ }^{12-15}$. Some modifications of the questionnaire were necessary, due to clinical conditions.

Out of 100 questionnaires, 75 were completed and returned. The response rate was thus $75 \%$, data were inserted and analysed using SPSS (Statistical Package for Social Sciences) 17.0. For the statistical analysis, we used the Pearson and Spearman correlation coefficients, linear regression (small squares method), statistical testing of the assumption of equivalence of averages and statistical testing of the assumption of the share. For the purposes of qualitative methodology, the interview consisted of eight questions, divided into five parts. Questions 1-3 were summarized by Sørensen and $B ø g h^{1}$ and $4-5$ by Salehi et al. ${ }^{11}$.

All the interviews were recorded and later transcribed. The text was divided into the components for coding units. Data were analysed with content analysis.

We tested three hypotheses:

$\mathrm{H} 1$ : Healthcare professionals who are more satisfied experience less stress while working with a brain-dead donor.

H2: Healthcare professionals who are undecided about the donation of their organs are against the donation of organs in general.

H3: Meeting a brain-dead donor with his relatives further exposes health professionals to more stress. 


\section{Results}

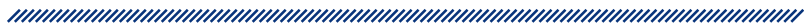

\subsection{Quantitative analysis}

The sample consisted of 57 (76\%) female and 18 (24\%) male participants. The majority of the respondents were aged from 31 to 50 years $(n=42 ; 56 \%)$, others belonged to the age group from 18 to 30 years $(n=28$; $37.3 \%)$, and five respondents (6.7\%) were over 50 .

More than a half of the sample had a college education - $1^{\text {st }}$ degree $(n=43 ; 57.3 \%)$, followed by compulsory education level $(\mathrm{n}=14 ; 18.7 \%$,), specialization or $\mathrm{PhD}(\mathrm{n}$ $=11 ; 14.7 \%$,) and college level of education $-2^{\text {nd }}$ degree $(n=7 ; 9.3 \%)$ (Table 1$)$.

Most of the respondents had from 2 to 20 years of work experience ( $n=59 ; 78.7 \%)$, followed by more than 20 ( $n$ $=14 ; 18.7 \%)$ and less than 2 years of work experience $(\mathrm{n}$ $=2 ; 2.7 \%)\left(p=0,000 ; x^{2}=72.240\right)$

\subsubsection{Work environment and stress}

The questions referring to the factors that are a source of stress at the workplace yielded the following results: an adequate amount of work ( $n=27 ; 36.5 \%)$, enough power and influence $(n=31 ; 41.9 \%)$ and the job that does not go beyond my ability ( $n=5 \% 27 ; 36.5 \%)$; leading and/or controlling the work of others: totally not true $(n=30 ; 40 \%), 12$ $(16 \%)$ totally true; concerns about "bringing work" back to their homes: 9 completely agreed (12\%), and 23 totally disagreed (30.7\%). Twenty-six (34.7\%) of the respondents were totally dissatisfied with the amount of payment, while four (5.3\%) were completely satisfied. Almost 30\% $(n=22)$ of the respondents neither agree nor disagree that their personal and organisational values and beliefs are aligned, while $43.2 \%$ do not believe themselves to be adequately managed. Most respondents do not feel undervalued $(n=29 ; 38.7 \%)$. More than a half $(n=38 ; 50.7 \%)$ of the sample partly or completely agrees with the statement that they can make important decisions (Table 2).

\begin{tabular}{|c|c|c|c|}
\hline \multicolumn{4}{|c|}{ Table 1. Level of education (n = 75) } \\
\hline Level of education & $\%$ & Profile & $\%$ \\
\hline Compulsory & 18.7 & Registered nurse/nursing assistant & 78.7 \\
\hline Higher education $-1^{\text {st }}$. degree & 57.3 & Doctor & 21.3 \\
\hline Higher education $-2^{\text {nd }}$. degree & 9.3 & & \\
\hline Specialization or PhD & 14.7 & & \\
\hline
\end{tabular}

\begin{tabular}{|c|c|c|c|c|c|c|c|c|c|c|c|}
\hline & \multirow[t]{2}{*}{ Statements } & \multicolumn{2}{|c|}{1} & \multicolumn{2}{|c|}{2} & \multicolumn{2}{|c|}{3} & \multicolumn{2}{|c|}{4} & \multicolumn{2}{|c|}{5} \\
\hline & & $\mathrm{f}$ & $\%$ & f & $\%$ & $\mathrm{f}$ & $\%$ & $\mathrm{f}$ & $\%$ & $\mathrm{f}$ & $\%$ \\
\hline S1 & I have just enough work to do. & 6 & 8 & 13 & 17.3 & 27 & 36 & 13 & 17.3 & 15 & 20 \\
\hline S2 & I have enough power and influence. & 6 & 8 & 22 & 29.3 & 31 & 41.3 & 10 & 13.3 & 5 & 6.7 \\
\hline S3 & My job does not go beyond my ability. & 2 & 2.7 & 8 & 10.7 & 27 & 36 & 19 & 25.3 & 18 & 24 \\
\hline S4 & I lead and/or control the work of others. & 30 & 40 & 15 & 20 & 8 & 10.7 & 10 & 13.3 & 12 & 16 \\
\hline S5 & I have concerns about my work at home. & 23 & 30.7 & 17 & 22.7 & 12 & 16 & 14 & 18.7 & 9 & 12 \\
\hline S6 & I am satisfied with the amount of payment. & 26 & 34.7 & 18 & 24 & 19 & 25.3 & 8 & 10.7 & 4 & 5.3 \\
\hline S7 & $\begin{array}{c}\text { My personal beliefs are consistent with the } \\
\text { organizational beliefs. }\end{array}$ & 15 & 20 & 26 & 34.7 & 22 & 29.3 & 12 & 16 & 0 & 0 \\
\hline S8 & $\begin{array}{l}\text { I am provided with appropriate guidance and } \\
\text { support from my superiors. }\end{array}$ & 10 & 13.3 & 22 & 29.3 & 32 & 42.7 & 10 & 13.3 & 0 & 0 \\
\hline S9 & $\begin{array}{l}\text { Consultation and communication available } \\
\text { in the team is sufficient. }\end{array}$ & 13 & 17.3 & 21 & 28 & 31 & 41.3 & 7 & 9.3 & 3 & 4 \\
\hline S10 & I get enough encouragement from my superiors. & 13 & 17.3 & 28 & 37.3 & 22 & 29.3 & 9 & 12 & 2 & 2.7 \\
\hline S11 & I do not feel undervalued. & 9 & 12 & 9 & 12 & 28 & 37.3 & 23 & 30.7 & 6 & 8 \\
\hline S12 & I participate in important decision-making. & 7 & 9.3 & 10 & 13.3 & 20 & 26.7 & 24 & 32 & 14 & 18.7 \\
\hline
\end{tabular}




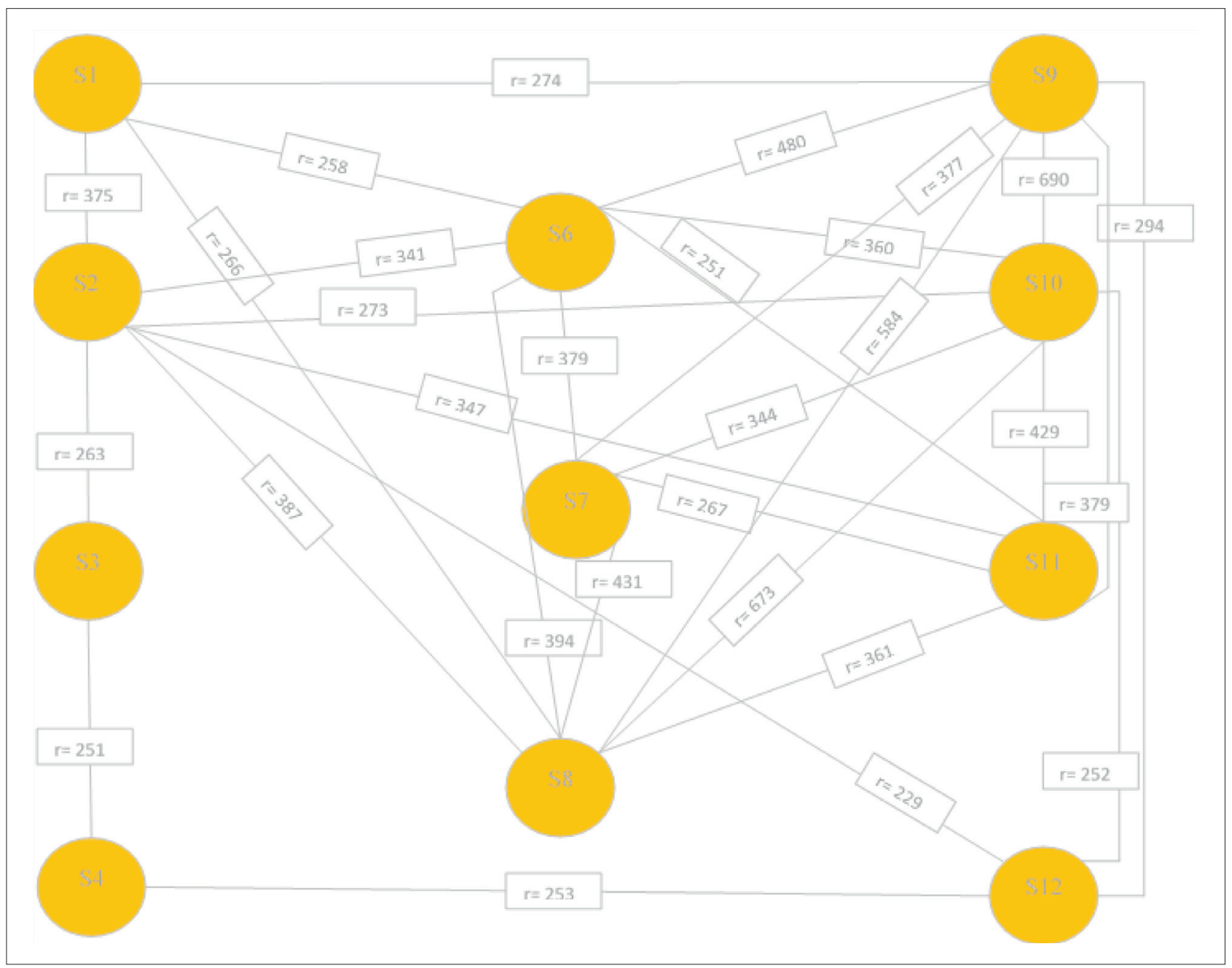

Fig. 1. Correlations between claims

A strong correlation between statements (see Table 1) is demonstrated in Fig. 1:

- S9 and S10 $(r=0.690)$ - healthcare professionals who feel that available communication and consultation among team members is sufficient also received sufficient incentives from superiors, and vice versa.

- S8 and S10 ( $r=0.673)$ - healthcare professionals who received sufficient incentives from their superiors are provided with proper guidance and support from their superiors, and vice versa.

- S8 and S9 $(r=0.584)$ - healthcare professionals who feel that available communication and consultation among team members is sufficient are provided with appropriate guidance and support from their superiors, and vice versa.
- S6 and S9 $(r=0.480)$ - the team members' satisfaction with the amount of payment and the level of communication are not related.

- S7 and S8 ( $r=0.431)$-healthcare professionals whose beliefs are in line with those of their organization feel that they are provided with proper guidance and support superiors, and vice versa.

- $\mathrm{S} 10$ and $\mathrm{S} 11(\mathrm{r}=0.429)$-healthcare professionals who received sufficient incentives from their superiors do not feel undervalued, and vice versa.

\subsubsection{Organ donation}

Within the sample, $54.7 \%$ of the respondents had experience with more than 15 brain-dead donors, while 34 (45.3\%) had experience with 1 to 15 . All the respondents 
had at least one experience with brain-dead donors ( $p$ $=0.419 ; x^{2}=0.653$.

In relation to the prejudice against organ donation, 40 (53.3\%), respondents stated that they did not have any prejudice against organ donation and supported the donation decision, 16 (21.3\%) were strictly against the donation, and the remaining $19(25.3 \%)$ were undecided $\left(p=0.001 ; x^{2}=13.680\right)$. Thirty respondents $(40 \%)$ declared that they were willing to donate their organs in case of death, and 26 (34.7\%) opposed the donation of their organs and $19(25.3 \%)$ did not express their attitude $\left(p=0.289 ; x^{2}=2480\right)$.

Fourteen (58.3\%) respondents opposed organ donation. The most common objections cited were religious beliefs $(n=2 ; 8.3 \%)$, fear $(n=1 ; 4.2 \%)$ and in seven cases (29.2\%) also inappropriate relationship with the donor, inappropriate attitude of colleagues to brain-dead people $\left(p=0.001 ; x^{2}=117.667\right)$.

Approximately one-third of the respondents $(n=23$; $31.1 \%$ ) would consent to organ removal of their relatives, while 24 (32.4\%) would not approve, and 27 $(36.5 \%)$ remained undecided or did not know how they would react in a real-life situation $\left(p=0.839 ; x^{2}=0.351\right)$.

\subsubsection{Work with brain-dead persons}

Different responses were given by healthcare professionals in the ICU in relation to patients' brain death. Fiftysix percent can work without any distraction, while 26 (34.7\%) express their fear in relation to death and grieving relatives. A few of the respondents $(n=23 ; 30.7 \%)$ requested additional information from their superiors and colleagues in relation to the healthcare of brain-dead patients. The remaining nine $(12 \%)$ were angry or sad because they worked with brain-dead patients.

Additional research is necessary into the work with braindead donors. The work-related stress levels were measured on a ten-point scale ( 1 - relaxed; 10 heavily burdened and stressed). More than half of the respondents $(n=39$; $52 \%)$ experience the stress at Level 7 or higher, 19 (25.3\%) at Levels 5 or 6 , and $17(22.7 \%)$ below Level $5\left(p=0.000 ; x^{2}\right.$ $=32.600)$. The respondents' self-assessment of the degree of concentration during the work with brain-dead donors established that $46(61.3 \%)$ respondents are focused on work as usual, $24(32 \%)$ are highly concentrated, three (4\%) cannot identify the offered answers, and $2(2.7 \%)$ cannot fully concentrate on their work (Fig. 2).

During the healthcare process of maintaining the organs of a brain-dead organ donor, different feelings are experienced, such as sadness ( $n=26 ; 35 \%$ ), anxiety ( $n$ $=23 ; 17.3 \%$ ), and other feelings ( $n=6 ; 8.5 \%)$. Thirty respondents (40\%) selected the answer "other" (Fig. 3.)

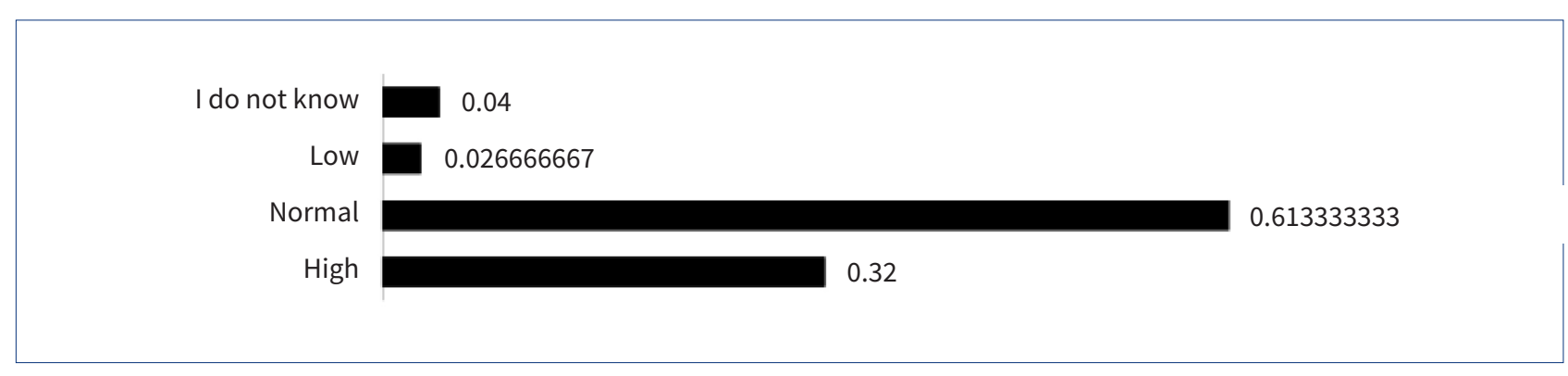

Fig. 2. Degree of concentration $(n=75)$

$p=0,000 ; x^{2}=19,987$

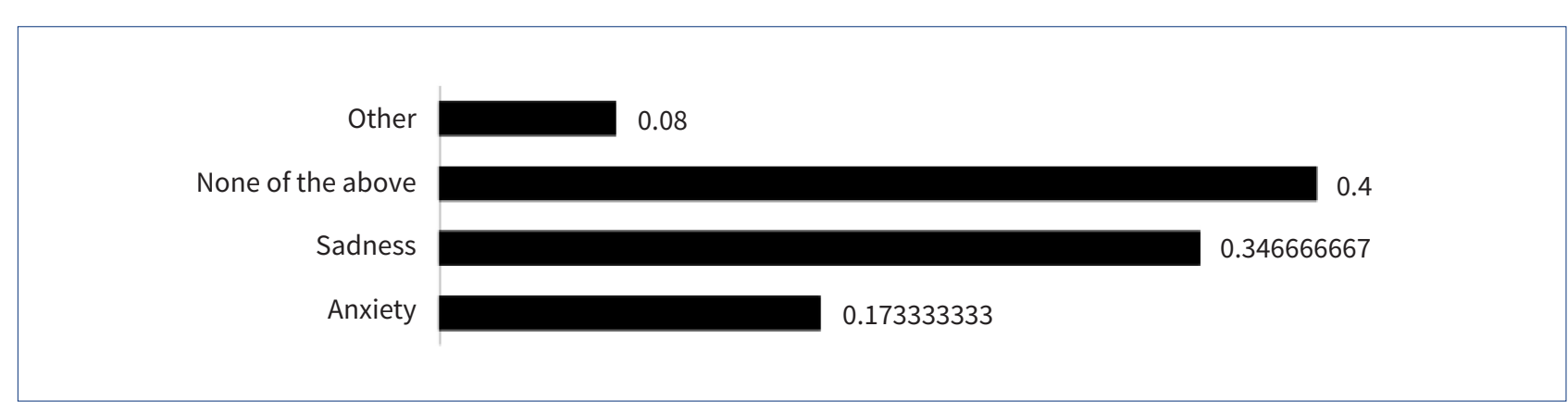

Fig. 3. Feelings experienced during management of a brain-dead organ donor $(n=75)$. $p=0.000 ; x^{2}=69.267$ 


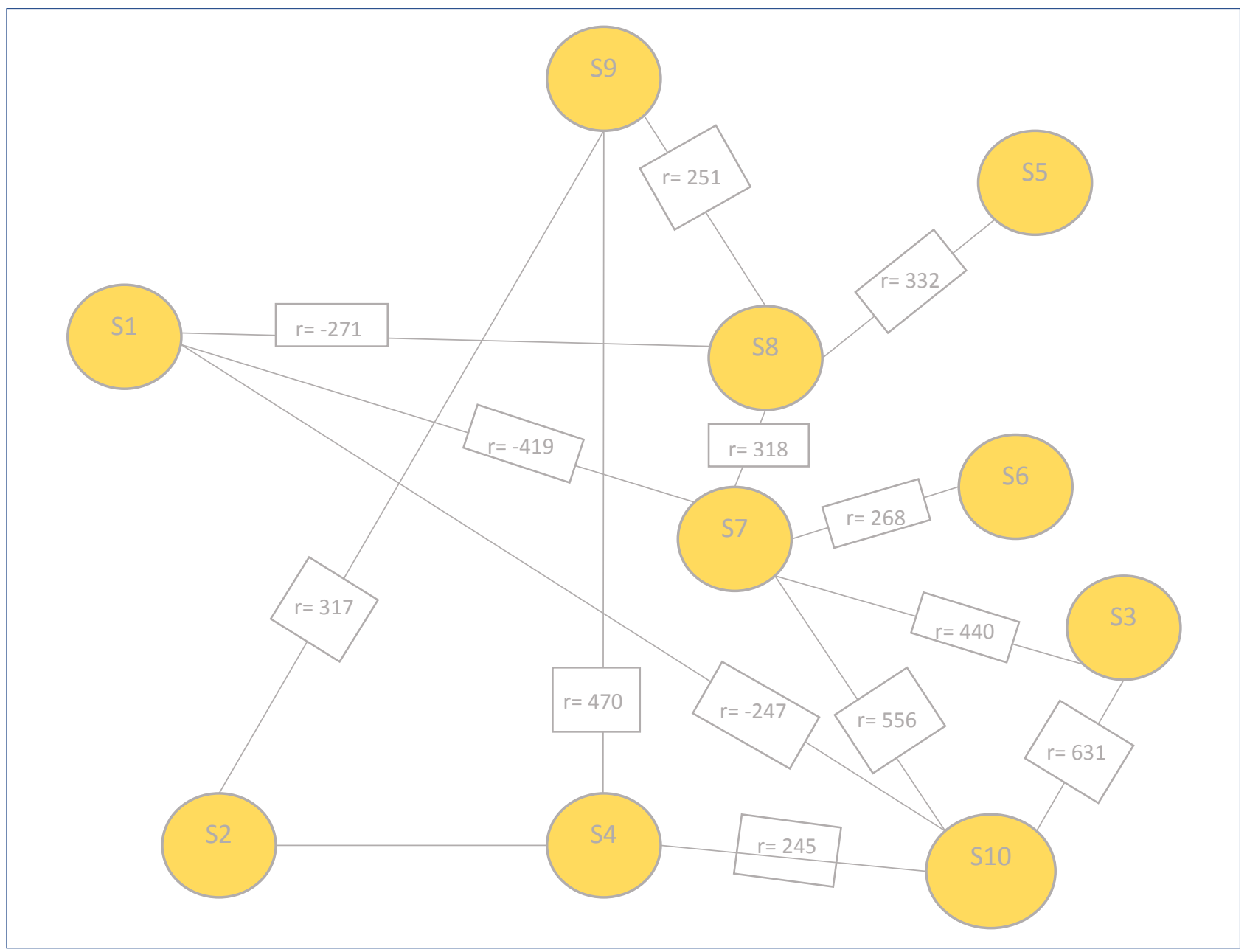

Fig 4. Correlation between healthcare professionals and working environment

Legend: S1 - I have decided not to think about the problem anymore; S2 - I try to get advice on what to do from other people; S3 - I use all my strength to solve the situation; S4 - I think that the situation is not real; S5 - In order to feel better and calm myself, I smoke a cigarette; S6 - I'm trying to get emotional support from colleagues; S7 - I vent my emotions; S8 - I try to look at the situation from another, more positive angle; S9 - I ask people with similar experiences how they coped with it; S10 - I experience a lot of stress and I notice that the emotions that occur there are clearly expressed.

The answer "other" included the respondents' reports of anxiety, bad feelings, additional workload that is highly demanding but not properly paid, scepticism whether all organs will be suitable for transplantation or they are only for completing the donor programme, extra work, and stress.

The wish to refuse to work with brain-dead organ donors was reported by nine (12\%) respondents, and they could justify their reasons, as summarized in the following:

- "Due to mental stress"

- "Yes, because the team members did not agree whether the patient really wanted it."

- "Sometimes we are more susceptible to additional stress at work due to personal problems and stress."
- "I find it unethical that a brain-dead donor can be at such an advanced age."

- "Too young brain-dead donor."

- "Due to additional diagnostics, especially a lot of work with other patients at the same time."

- "Because it is psychologically stressful."

The remaining study participants $(n=66 ; 88 \%)$ did not report the desire to refuse to work $\left(p=0.000 ; x^{2}=43.320\right)$.

Most of the statistically significant differences were weak, and others were negative. We will highlight the strongest (Fig. 4):

- $\mathrm{S} 3$ and $\mathrm{S} 10(r=0.631)$ - healthcare professionals who use all their strength to solve the situation also express the emotions that emerge in stressful situations, and vice versa. 
- $\mathrm{S} 7$ and $\mathrm{S} 10(\mathrm{r}=0.556)$ - healthcare professionals who vent their feelings also ask people with similar experiences what they did, and vice versa.

- S4 and S9 $(r=0.470)$ - healthcare professionals who in a stressful situation help themselves by pretending that the situation is not real also ask individuals with similar experience how they coped with it, and vice versa.

- S3 and S7 $(r=0.440)$ - healthcare professionals who use all their strength to solve the situation also vent their feelings, and vice versa.

- S1 and S7 ( $r=-0.419)$ - a more negative correlation - healthcare professionals who vent their feelings do not devote themselves to work without thinking about the problem, and vice versa.

\subsubsection{Relief techniques}

The findings show that the respondents clearly express their need for assistance in case of work overload. Most of the respondents $(n=45 ; 60 \%)$ ask for debriefing, 43 (57.3\%) practice relaxation techniques, supervision, team building, etc. (Fig. 5). Others talk to their partner $(n=43$; $57.3 \%)$ or their colleagues $(n=40 ; 5.3 \%)$ and friends $(n=$ $32 ; 42.7 \%)$, or seek other forms of assistance $(n=5 ; 6.7 \%)$.

\subsubsection{Relatives as an additional burden}

A large percentage of respondents $(n=43 ; 58.1 \%)$ reported that the encounter with the relatives of the deceased additionally burdened them, while 31 (41.9\%) do not perceive it as burdensome $\left(p=0.163 ; x^{2}=1.946\right)$. It can be concluded that relatives represent an additional burden. Key concepts are relatives' mourning and pain, approach to and communication with grieving relatives, and general sadness about death.

\subsection{Qualitative analysis}

In the qualitative analysis, each question was united in the common denominators. The letter in the brackets represents an interviewee (Table 3a-c).

\section{Hypotheses}

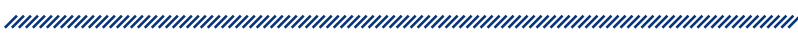

HO: Satisfaction of healthcare professionals does not affect the level of stress in working with a brain-dead donor.

H1: Healthcare professionals who are more satisfied experience less stress while working with a brain-dead donor.

Based on the statistical analysis, we rejected the alternative hypothesis $(\mathrm{H} 1)$, and we could not reject the null hypothesis $(\mathrm{HO})$. The statistical analysis did not show an essential link between the general level of work satisfaction and the stress caused by working with braindead donors. It can be concluded that working with a brain-dead donor is a specific situation and has little in common with factors that affect the general satisfaction of health professionals. However, we found that women on average experience more stress in working with brain-dead donors than men do.

For testing the hypothesis of the influence of healthcare professionals' satisfaction on the level of stress, we introduced a new variable, Satisfaction sum, which represents the sum of scores of individual factors from the source of stress (set of claims - no. 5 in the questionnaire). All factors were included, except the $4^{\text {th }}$ and $5^{\text {th }}$ claims. A higher rating of the factor meant a higher

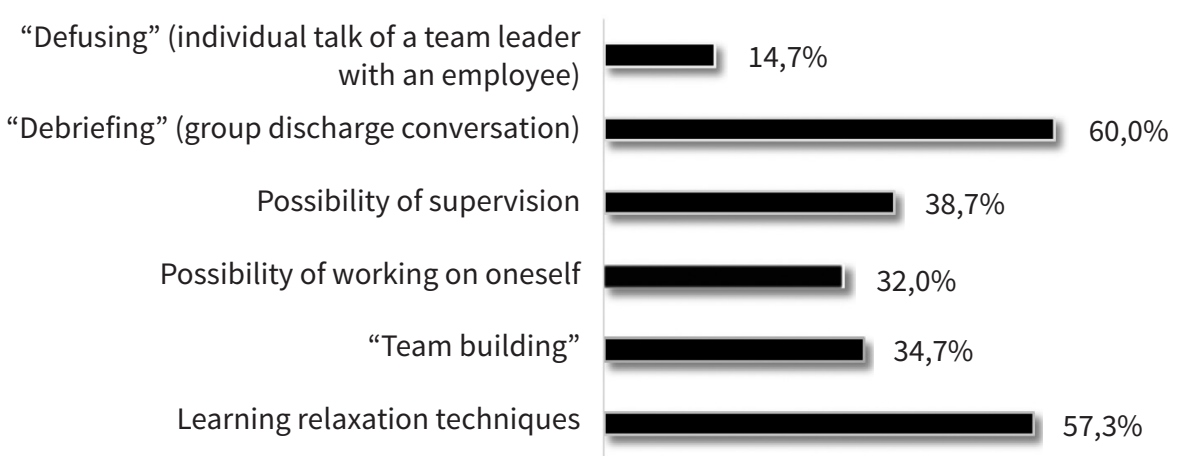

Fig. 5. Stress relief techniques $(n=75)$. 


\begin{tabular}{|c|c|c|}
\hline QUESTION & CODE & ANSWER \\
\hline \multirow[b]{2}{*}{$\begin{array}{l}\text { 1. What is your attitude } \\
\text { towards organ donation for } \\
\text { transplantation? }\end{array}$} & $\begin{array}{l}\text { FOR ORGAN } \\
\text { DONATION }\end{array}$ & $\begin{array}{l}\text { "I would donate my organs; it would be nice if I could help. I would } \\
\text { immediately donate my organs to my relatives". (A) } \\
\text { "Human life needs donors of survival organs. Depending on the } \\
\text { situation, the role of a relative and the donor differ." (B) } \\
\text { "I have a positive attitude. I support transplantation and I think it is } \\
\text { humane and necessary." (D) }\end{array}$ \\
\hline & $\begin{array}{l}\text { AGAINST ORGAN } \\
\text { DONATION }\end{array}$ & $\begin{array}{l}\text { "In principle, I am against it because I would want to bury my family } \\
\text { with all their organs." (A) } \\
\text { "I know how things are; I know what the process is, and this is my } \\
\text { fear." (B) } \\
\text { "I have concerns about the practice, the routine attitudes of } \\
\text { doctors, the lack of respect, especially towards relatives. I am upset, } \\
\text { people deserve a more respectful attitude, I am against it." (C) } \\
\text { "I cannot figure it out, I think it's hard for young people. If I did not } \\
\text { work in healthcare, it would be even harder to decide." (B) }\end{array}$ \\
\hline \multirow[t]{2}{*}{$\begin{array}{l}\text { 2. Have you talked with your } \\
\text { family about donation after } \\
\text { death? }\end{array}$} & YES & $\begin{array}{l}\text { "We have. In principle, everyone would donate their organs. The } \\
\text { question is, however, how to decide if they are a friend who needs } \\
\text { to give consent." (A) } \\
\text { "Yes, with my son. He's of the opposite opinion than me. He is } \\
\text { absolutely for organ donation. My daughter has doubts, though." (C) } \\
\text { "We have talked, but I must say their awareness of this topic is low. } \\
\text { I started this topic on many occasions, and everyone agrees except } \\
\text { for one; he thinks he does not know what the family would have to } \\
\text { do with it. It turns out that someone is doing a good job." (D) }\end{array}$ \\
\hline & NO & $\begin{array}{l}\text { "No, we have not. I do not even know if my family would agree. This } \\
\text { is a sensitive subject; we never talk about death in general." (B) }\end{array}$ \\
\hline
\end{tabular}

level of satisfaction. In the next step, we used the variable Satisfaction_sum to test the variable Stress (set of claims - no. 12 in the questionnaire). We used linear regression with the independent variable Satisfaction sum and the dependent variable Stress, which showed a weak negative impact on the assessment of stress when working with a brain-dead donor. This means that a higher level of satisfaction at work allows lower levels of stress when healthcare professionals work with a brain-dead donor. The linear model itself, as well as the constant and the regression coefficient, were statistically significant, but there is a weak correlation because the improvement of 10 points in the overall satisfaction assessment (Satisfaction_sum) reduce the rating of stress for 1 point on the scale from 1 to 10 . This also indicates a determination coefficient of 0.054 and represents the low predictive power of the model.

Furthermore, the correlation between the variables Satisfaction_sum and Stress showed weak, linear and negative correlation. The Pearson coefficient was -0.232 , and it was statistically significant, while the rank of Spearman's coefficient was -0.192 , and it was not statistically significant. Based on the variable Satisfaction_sum as at least an interval range, and the variable Stress as an ordinal rank, we used a Spearman's rank coefficient, which does not indicate the correlation between variables at the level of the entire sample. Finally, we did not find a solid link between satisfaction and stress when working with a brain-dead donor.Based on the median and the average of the variable Satisfaction_sum, which amounted to 32.00 and 32.09 , we divided the respondents into two groups. Respondents with the sum over 32.00 were included in the group of healthcare professionals who are more satisfied, and others in the less satisfied group. The t-test did not find a statistically significant difference between the variable Stress and the other groups.

Furthermore, we tested the differences between the average of the variable Stress and gender. Here, the test revealed statistically significant differences at insignificant risk. Women assess a significantly higher level of stress when working with brain-dead donors than men do. The average of stress in the sample estimates (scale from 1 to 10 , where 10 is the highest level of stress) was 7.23 for females, while in males it was 3.78. The differ- 


\section{Table 3b. Qualitative analysis of interviews ${ }^{16}$}

\section{QUESTION}

Do you think that you have enough theoretical and practical knowledge to explain to someone what cerebral death is, and do you have enough knowledge to work with a brain-dead donor?

What makes you most exhausted when working with a brain-dead patient? Have you ever noticed a conflict between feelings and duty to work?

\section{CODE}

EXHAUSTION
FACTORS
What makes you most exhausted
when working with a brain-dead
patient? Have you ever noticed a
to work?

ences in satisfaction or level of stress could not be tested for groups with different years of work experience, as only two respondents were in the group with little work experience (less than two years of work experience), which is insufficient for credible testing.

H0: Healthcare professionals who are undecided about the donation of their organs are against organ donation in general.

\section{ANSWER}

"No." (A)

"I think that theoretical knowledge is never enough." (C) "I'm glad that doctors say this: 'I think it's hard to find the right words.' Personally, I would not be able to explain it well." (D) "No. Nobody has ever explained anything to me; everything you hear is silence after the doctors. I have gained enough

experience for routine work, but when my relatives get involved, it's difficult. At such time, I could hardly explain it to myself. I'm not sure whether I believe in cerebral death. I believe more in traditional death." (A)

"I do not know... yes and no. We never mentioned it in college courses. I haven't worked a lot with brain-dead donors. The number of lectures is insufficient; there could be some kind of workshop." (B)

"Theoretical knowledge is never enough. Regular training sessions are insufficient. In all my years of service ( 25 years) I have not received any official information or instructions on how to work with a brain-dead person. Everything is routine,

mechanical, and there's very little human touch." (C)

"No, not at all. After five years of working in intensive care, I attended my first training this year." (D)

"Theoretically, I think that I could explain it properly. The question remains whether they would understand." (B)

"The most exhausted - the preparation of a brain-dead donor and relatives. Yes, relatives. When they come to say goodbye, if you do not bury it ... I do not know what you are. And hand over the patient to the operating theatre..." (A)

"I get too emotional. I have to distance myself; otherwise, you do not survive in such an environment. It's exhausting to meet them, I really feel sorry for them. Nothing is provided for them. Otherwise, in terms of work, it should not be more stressful, since established routines exist. Working with the donor is definitely psychologically more stressful unless you work mechanically." (C)

"Psychologically, I'm exhausted. I still do not accept that a man is dead. Poor organization of work, too much work and specialists at one time. Intolerance." (D)

"I have never refused, most likely I never will. But there is already such a moment when you do not want to be deep inside." (A)

"Never. It is true that every day I turn to my homework 'once again', even for situations such as donors." (B)
H1: Healthcare professionals who are undecided about the donation of their organs are not explicitly against organ donation in general.

In the sample, no one has explicitly opposed organ donation in general. Although we could not test the assumptions on the sample, since the condition for the use of the test was not fulfilled, the survey showed that it is probably a negligible proportion of healthcare professionals 


\begin{tabular}{|c|c|c|}
\hline QUESTION & CODE & ANSWER \\
\hline $\begin{array}{l}\text { 6. What makes you most } \\
\text { exhausted when you work with a } \\
\text { brain-dead donor? Have you ever } \\
\text { noticed a conflict between feelings } \\
\text { and duty to work? }\end{array}$ & NO REFUSAL & $\begin{array}{l}\text { "In fact, I have not because I've never thought of it. However, } \\
\text { in my mind, there are a few difficult examples. For example, } \\
\text { the Lazarus phenomenon. It is obvious that it was creepy, } \\
\text { and then mommy had to say goodbye to her daughter." (C) } \\
\text { "I do not think so. But it was annoying when we were } \\
\text { witnessing reflexes, then you wonder if this is really just a } \\
\text { spinal reflex." (D) }\end{array}$ \\
\hline \multirow{2}{*}{$\begin{array}{c}\text { 7. What is your relationship with } \\
\text { relatives? Do you have a lot of } \\
\text { contact with them? Would you } \\
\text { like to attend the reporting of bad } \\
\text { news? }\end{array}$} & $\begin{array}{c}\text { RELATIONSHIP WITHOUT } \\
\text { CONTACT }\end{array}$ & $\begin{array}{l}\text { "There is almost no contact between us." (A) } \\
\text { "I've never had any contact with them, you do not get a } \\
\text { chance at all". (B) } \\
\text { "We do not have any connections with the family. We should } \\
\text { have some, it is necessary. Behind the affected people, we } \\
\text { walk like robots. I was in contact when I accompanied them } \\
\text { to the deceased. You do not know how to behave; we do not } \\
\text { have the required knowledge." (C) } \\
\text { "I cannot even say that there is a relationship between us. } \\
\text { I already pronounced my sights, but I did not know if they } \\
\text { actually realized that somebody died. An ER nurse should } \\
\text { have more contact." (D) }\end{array}$ \\
\hline & WISH TO BE PRESENT & $\begin{array}{l}\text { "I want to be present, I'm interested in the process, and I } \\
\text { would like to explain it to them. It would be good to have } \\
\text { an approximate picture of how the conversation should } \\
\text { take place. Maybe you clarify certain things by yourself. Our } \\
\text { training is insufficient." (A) } \\
\text { "I would cooperate because I cannot reach my relatives. Very } \\
\text { few of us are involved in these things, we are like some sort of } \\
\text { article of the last resort." (B) } \\
\text { "Cooperation should be more professional." (C) } \\
\text { "It is imperative that we have more contact with relatives, } \\
\text { but I think in cooperation with a doctor. It would make sense } \\
\text { if a doctor was with us." (D) }\end{array}$ \\
\hline
\end{tabular}

who are undecided about the donation of their organs and have explicitly opposing beliefs or prejudice against the donation of organs.

In analysing how general beliefs in relation to organ donation affect the decision to donate their organs, we have the following findings. Among those who support organ donation $(n=40), 67.5 \%$ of respondents were willing to donate their organs, $20 \%$ did not know, and $12.5 \%$ will not give their organs. We can also conclude that more than $50 \%$ of healthcare professionals who support the donation of organs are ready to donate their organs. The test is statistically significant at $p=0.0134$.

Respondents who in general do not support organ donation $(n=16)$ replied that they would not give their organs. We did not test these assumptions due to the small size of the sample, and the condition for using the test was not met. The remaining ones with unspecified general beliefs about organ donation $(n=19)$ responded to the donation of their organs in the following way: $57.9 \%$ did not know, $26.3 \%$ would not donate organs, and $15.8 \%$ would donate the organs. We did not statistically test these assumptions, for the same reasons as before.

As for the consistency of the decisions regarding the donation of their bodies (question no. 8 in the questionnaire) and the willingness to give consent for the removal of organs to a close relative (question no. 10 in the questionnaire), we had only three cases (out of 74 respondents who answered both questions) giving exclusively polar responses (that is, they would donate organs, but they would not give consent for close relatives or vice versa). In all other cases, the decisions were in the same direction (yes, yes or no, no) or were not sure (they did not know the answer to at least one question). Depending on the significant percentage, which 
tends to confirm, we decided to confirm the hypothesis.

$\mathrm{HO}$ : Meeting with the family of a brain-dead donor does not burden the healthcare professionals.

H1: Meeting with the relatives of a brain-dead donor exposes the healthcare professionals to additional burden.

We confirm the alternative hypothesis $(\mathrm{H} 1)$ and reject the null hypothesis $(\mathrm{H} 0)$.

To test the hypothesis about the additional burden on healthcare professionals when they meet brain-dead donors' relatives, we used question no. 28 in the questionnaire. We tested whether the proportion of healthcare professionals (more than 50\%) who are additionally burdened by the encounter with brain-dead donors' relatives. The share was $58.1 \%$, which was not enough to conclude for the entire sample at $5 \%$ risk, since the one-sided test value was $p=0.0817$, which means that it could be concluded for the whole sample, in acceptance of the risk of misstatement of over $8 \%$. However, we can confirm the hypothesis that the proportion of healthcare professionals who are additionally burdened by the encounter with the relatives of brain-dead donors is more than $45 \%(p=0.0118)$. Although we cannot statistically confirm that this was the majority of healthcare professionals, we can argue that this is a significant proportion that is additionally burdened by an encounter with relatives; therefore, the hypothesis is confirmed.

\section{Discussion}

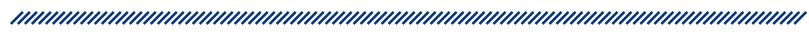

Based on the sample, the healthcare professionals in the ICU were relatively young. Based on obtained data on gender and age, we could theoretically generalize on the population. Women between 20 to 30 years old, with at least college education and more than two years of work experience, think and feel that they have enough work in the workplace. The managerial aspect appears in men, who are over 50 and have college education.

Based on independent variables and the correlation of claims ( $5^{\text {th }}$ question), we can confirm that respondents who feel that they have power and are capable of performing quality work are satisfied with the amount of payment, have proper guidance and superiors' support, and make appropriate decisions. Respondents without personal conflict situations think that consultations are sufficient and respectful communication exists. Furthermore, respondents who have proper guidance and support in the workplace think that they received sufficient incentives from their superiors. However, authors have argued that work and care for brain-dead donors or possible donors represent difficult work, especially in the case of hemodynamically unstable donors ${ }^{17}$.

Most of the respondents support organ donation $(n=$ $30 ; 40 \%$ ) and organs will be donated based on their support of transplantation activities and their willingness to help others.

As expected, some respondents disagreed with organ removal. Similar factors are present in the research of Organ and Tissue Donation Knowledge Among Intensive Care Unit Nurses ${ }^{18}$ : fear of death, ignorance and misunderstanding of the term "brain death", lack of information regarding the organ transplantation, religion, negative experiences in the healthcare system, and general opinions about body abuse and disrespect for the dead body, and other negative opinions about organ donation $n^{6,18}$. We conclude that the most common reasons against donation are the ignorance of the system and the functioning of the transplant network, and the desire to bury a family member as a whole.

The confrontation with the newly discovered possible dead donor for most respondents is not stressful, but in general, according to the obtained data, those working with a brain-dead donor were divided into three groups, which leads to the conclusion that more than half of the respondents feel stressed or very stressed.

Regarding exhaustion in the work environment in relation to the dead donor, answers were also negative and undefined. On the negative side, the most prevalent were pain and suffering of relatives, a way of work and attitude, and young donors etc. Ralph et al. highlight the dangerous effect of mistrusting transplantation ${ }^{19}$. Meyer, Bjørk, and Eide revealed a dangerous effect of the lack of knowledge ${ }^{20}$. However, based on our data, during the work with brain-dead donors, healthcare professionals were highly focussed; at the same time, a possibility for unwanted phenomena of repressing their emotions exists. 


\section{Conclusions and recommendations}

Given the fact that organ and tissue transplantation is becoming an increasingly established method of treating incurable diseases worldwide, we can say that Slovenia is also on track to achieve an increasing number of organs and tissues transplanted. The people of Slovenia can decide for themselves whether they are willing to donate their organs after they die. In the event of a serious accident or injury, where the diagnosis of brain death occurs, organ donation is decided upon by the deceased's closest relatives. The conditions are the diagnosis of brain death, the preserved functioning of organs or tissues, excluding incurable diseases and infections.

This process cannot take place without employees in healthcare. Doctors and nurses who work in intensive care units are people who are constantly with their patients. It is not always the case that due to workloads, they are subject to stress and the negative effects that such work may cause.

\section{References}

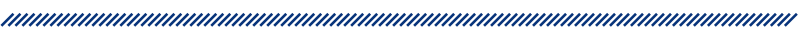

1. Sørensen $P, B ø g h$ L. Change of attitude in relation to organ donation. A comparative analysis over ten years. Organ, tissues and cells. 2013; (16): 107-111.

2. Young GB. Diagnosis of brain death. 2013. [Internet] Available from: http://mehr.tums.ac.ir/Upload/Journal/1969353cad0f-4615-bffd-fde1d1dccdb9.pdf (accessed 25 Nov 2015).

3. Murthy C. Organ Donation: Intensive Care Issues in Managing Brain Death. MJAFI 65. 2009. [Internet] Available from: http://medind.nic.in/maa/t09/i2/maat09i2p155. pdf (accessed 25 Nov 2015).

4. Pearson A, Robertson Malt S, Walsh K, Fitzgerald M. Intensive care nurses' experiences of caring for brain death organ donor patients. Journal of Clinical Nursing. 2001; 10(1): 132-139.

5. Cavalcante LP, Ramos IC, Marques Araujo MA, Santos Alves MD, Batista Braga VA. Nursing care to patients in brain death and potential organ donors. Acta Paulista Enfermagem. 2014; 27(6): 567-272.

6. Fenner H, Buss C, Gardiner D. Intensive care staff attitudes to deceased organ donation. The intensive Care Society. $2014 ; 15(1)$ : 53-56.
7. Floden A, Berg M, Forsberg A. ICU nurses' perceptions of responsibilities and organisation in relation to organ donation - A phenomenographic study. Intensive and Critical Care Nursing. 2011; 27: 305-316.

8. Floden A. Attitudes towards organ donor advocacy among Swedish intensive and critical care nurses. Gothenburg: University of Gothenburg, 2011.

9. Strauss AL. Qualitative analysis for social scientists. San Francisco: Cambridge University Press, 1995.

10. Bowling A. Research methods in health: investigating health and health services. Buckingham, Philadelphia: Open University Press, 2002.

11. Salehi S, Kanani T, Abedi H. Iranian nurses' experiences of brain death donors care in intensive care units: A phenomenological study. Iranian Journal of Nursing and Midwifery Research. 2013; 18(6): 475-482.

12. Goldberg D (1972). Splošni vprašalnik o zdravju. In: Tabaj $\mathrm{S}$ et al. Stres pri delu, zadovoljstvo z delom, izgorelost in strategije spoprijemanja s stresom delavcev na področju zaposlitvene rehabilitacije 2010. Ljubljana: Univerzitetni rehabilitacijski inštitut Republike Slovenije-Soča, 2010: 8.

13. Carver CS, Scheier MF, Weintraub JK. Assessing Coping Strategies: A Theoretically Based Approach. Journal of Personality and Social Psychology. 1989; 56(2):267-283.

14. Mooney CD. Nurses and Post-mortem Care: A Study of Stress and the Ways of Coping. Australia: Faculty of Health Science, 2002.

15. Croxson M. Stres pri delu. In: Tabaj S et al. Stres pri delu, zadovoljstvo z delom, izgorelost in strategije spoprijemanja s stresom delavcev na področju zaposlitvene rehabilitacije 2010. Ljubljana: Univerzitetni rehabilitacijski inštitut Republike Slovenije-Soča, 2010: 4-6.

16. Urbič P. Donation - experience of health care workers in the maintenance of a brain death donor. Master thesis. Ljubljana: Faculty of Health Sciences, 2015.

17. Guido LA, Linch GFC, Andolhe R, Conegatto CC, Tonini CC. Stressors in the nursing care delivered to potential organ donors. Revista Latino-Americana de Enfermagem. 2009; 17(6): 1023-1029.

18. Shabanzadeh AP, Sadr SS, Ghafari A, Nozari BH, Toushih M. Organ and tissue donation knowldge among intensive care unit nurses. Transplantation Proceedings. 2009; 41(5): 1480-1482.

19. Ralph A, Chapman JR, Gillis J, Craig JC, Butow P, Howard K, Irving M, Sutanto B, Tong A. Family Perspectives on Deceased Organ Donation: Thematic Synthesis of Qualitative Studies. American Journal of Transplantation. 2014; 14 (4): 923-935.

20. Meyer K, Bjørk I, Eide H. Intensive care nurses' perceptions of their professional competence in the organ donor process: a national survey. Journal of Advanced Nursing. 2012; (68)1: 104-115. 


\section{DARIVANJE ORGANA: ISKUSTVO U ODRŽAVANJU MOŽDANO MRTVOG DONORA S NA ŽIVOTU}

1 Petra Urbič Jurak

2 Andrej Starc

1 Medical Centre Rogaška Slatina, Zdravstvo d.o.o.

2 Fakultet zdravstvenih studija, Katedra za javno zdravstvo, Sveučilište u Ljubljani, Slovenija darivanja organa. Utvrđeno je da postoji nedostatak obrazovanja i komunikacije o održavanju moždano mrtvih donora na životu.

Zaključci: Rad s moždano mrtvim donorima gotovo je rutinski posao u jedinicama intenzivne skrbi. Neki zdravstveni djelatnici percipiraju moždano mrtve donore kao i sve ostale pacijente, ali unutar definiranog protokola.

\section{Sažetak}

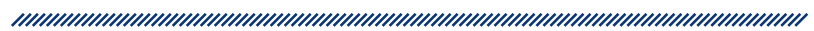

Pozadina: Moždana je smrt nepovratni biološki događaj koji podrazumijeva stalni prekid funkcija mozga i moždanog debla. Postupak transplantacije postao je uspješna metoda liječenja mnogih pacijenata s terminalnim stanjima bolesti.

Metodologija: Uzorak se sastojao od tri skupine: liječnika, registriranih medicinskih sestara i njegovatelja. Istraživanje je provedeno u jedinici intenzivne skrbi Sveučilišnog kliničkog centra u Ljubljani, na Odjelu za anesteziologiju i intenzivno kirurško liječenje te na Odjelu za vaskularnu neurologiju i intenzivno neurološko liječenje. Podaci su prikupljeni putem upitnika i polustrukturiranih intervjua.

Rezultati: U slučaju rada s moždano mrtvim donorima, stres utječe više na žene nego na muškarce. Zaključujemo da rad s moždano mrtvim donorom organa predstavlja specifičnu situaciju i nema mnogo zajedničkog s čimbenicima koji utječu na ukupno zadovoljstvo zdravstvenih djelatnika. Zdravstveni djelatnici koji su neodlučni oko darivanja vlastitih organa općenito su protiv

Ključne riječi: smrt mozga, postupak transplantacije, moždano mrtav donor organa, stres, iskustva zdravstvenih djelatnika. 